\title{
Tinjauan Penyaluran Dana BSPS di Desa Tusan, Kecamatan Banjarangkan, Kabupaten Klungkung
}

\author{
Ni Luh Putu Juniartini \\ Fasilitator Lapangan (TFL) SNVT PUPR \\ Email: juniraditya@gmail.com
}

\begin{abstract}
A decent house is everyone's dream, but in reality, there are still many houses that are still not up to standard. In Tusan Village, Banjarangkan District, Klungkung Regency through the BSPS PUPR program, 50 houses were allocated assistance. Procedurally, these houses are houses that have very unfit verification. Based on data from village officials and proposals that have been required, the recipient of the assistance must go through the submission process according to the rules. In the field process, there are three crucial constraints in broad outline and require intensive assistance solutions so that the BSPS program runs according to the initial planning. The synergy between the community, village officials, and the government is also needed in this process so that significant obstacles can be resolved in accordance with applicable regulations. In the end, this program can run on target and can also be enjoyed by the community in Tusan Village.
\end{abstract}

Keywords: house, livable, village, tusan, klungkung.

\section{PENDAHULUAN}

Rumah atau tempat tinggal adalah bagian dari kebutuhan manusia dari kebutuhan ketiga atau tersier (pangan, sandang, papan). Pada pemenuhannya, rumah mesti memiliki kesesuaian dalam berbagai aspek dalam pembangunannya temasuk keamanan dan kenyamanan. Pemenuhan aspek-aspek ini tentu akan meningkatkan kualitas hunian atau kelayakan hunian mengingat fungsinya sebagai tempat bernaung. Pada beberapa kasus, kelayakan yang dimaksud berdampak pada kekuatan elemenelemen yang ada dalam pembangunan suatu rumah halnya struktur, pondasi dan sebagainya dalam pembangunan. Kriteria layak huni juga di jelaskan berbagai pihak sebagai acuan, halnya pemerintah melalui PUPR dan WHO pada kategori rumah sehat.

Berdasarkan infografis (gambar 1) dari Direktorat Jenderal Pembiayaan Perumahan Kementerian Pekerjaan Umum dan Perumahan Rakyat (PUPR), rumah layak huni meupakan rumah yang memenuhi persyaratan keselamatan bangunan dan kecukupan minimum luas bangunan minimum $9 \mathrm{~m} 2 /$ orang serta kesehatan penghuninya. Rumah layak huni harus memenuhi keandalan komponen struktur sloof, kolom, ring, dan atap yang kokoh serta tidak mengalami permasalahan terkait struktur halnya retakan (ulasan sekilas pada gambar 2). Hal ini disertai pula dengan peningkatan kualitas bahan komponen non struktur seperti atap, lantai dan dinding. Pencahayaan, penghawaan, sanitasi menjadi syarat mutlak seperti halnya sumber air bersih atau ketersediaan jaringan air bersih, penyediaan tempat pembuangan sanitasi yang berfungsi baik, aman dan tidak mencemari lingkungan. Hal berikutnya disertai utilitas jaringan listrik yang berfungsi untuk kebutuhan sehari-hari penghuninya. 


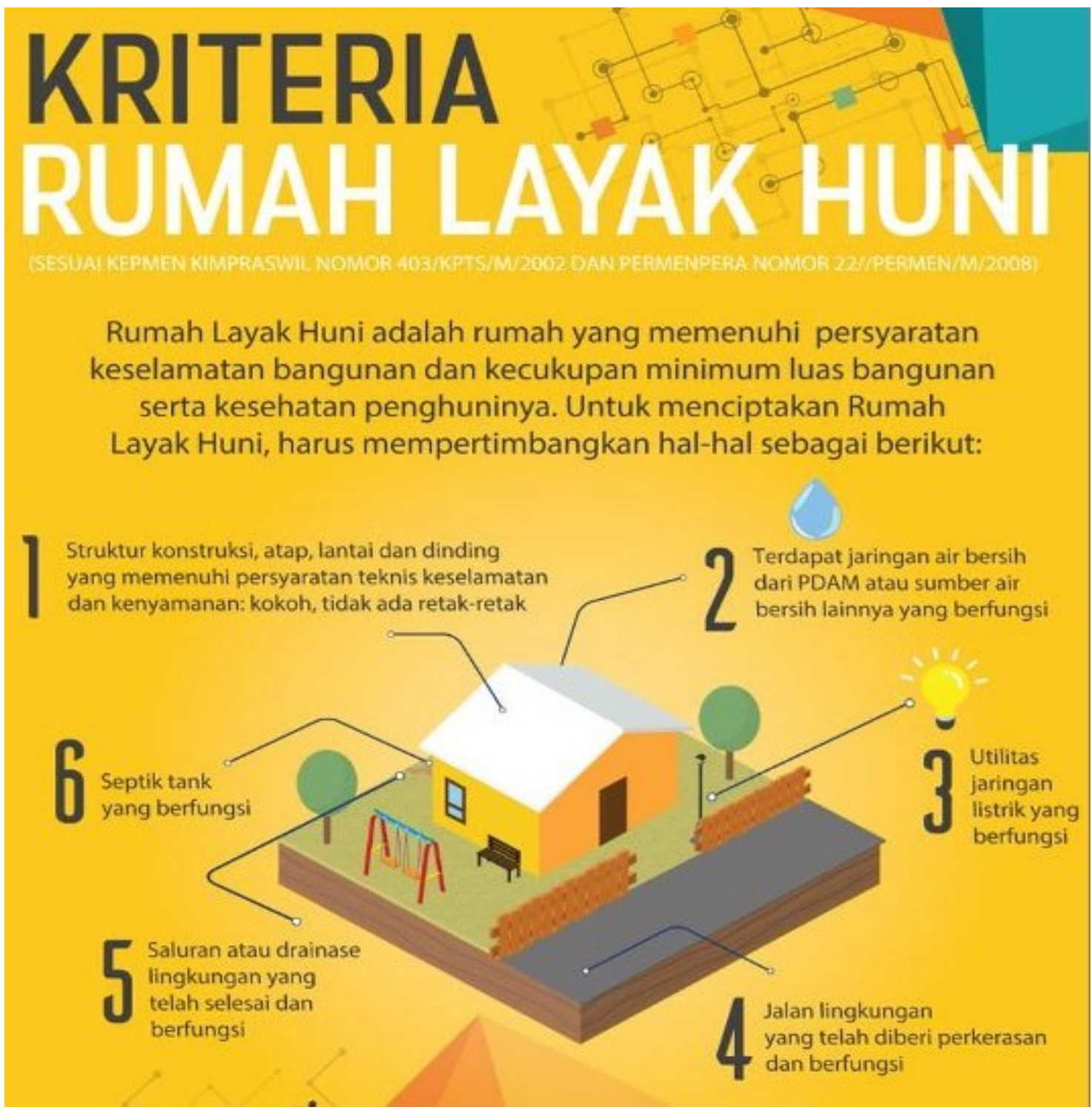

Gambar 1: Infografis kriteria rumah layak huni. Sumber: Kementerian PUPR.

Rumah tidak layak huni merupakan suatu hunian atau tempat tinggal yang tidak memenuhi kriteria/persyaratan, baik secara teknis maupun non teknis. Kondisi rumah yang dimaksud diantaranya luas bangunan yang sempit atau hanya mendukung fungsi ruang yang terbatas, sumber air tidak sehat, akses memperoleh air bersih terbatas tidak mempunyai akses mandi, cuci, kakus. Bahan bangunan tidak permanen atau atap/dinding dari bambu/rumbia. Tidak memiliki pencahayaan matahari dan ventilasi udara yang berfungsi baik atau tidak berfungsi sama sekali, lantai dari tanah dan rumah yang relatif lembab, tata letak rumah tidak teratur dan berhimpitan. Rumah tidak layak huni yang akan dibahas serta menjadi obyek dari penelitian ini terdapat di Desa Tusan kecamatan Banjarangkan Kabupaten Klungkung dan terdapat 50 rumah penerima bantuan.

Pada program Bantuan Stimulan Perumahan Swadaya (BSPS) ini, Desa Tusan Kecamatan Banjarangkan Kabupaten Klungkung puluhan rumah mendapatkan bantuan. Namun proses ini didasari atas mekanisme yang berlaku sesuai dengan Peraturan Menteri Pekerjaan Umum dan Perumahan Rakyat Republik Indonesia No 
07/PRT/M/2018 tentang BSPS, sehingga tepat sasaran bagi masyarakat yang membutuhkan dan memiliki inisiatif dalam membangun rumah kategori layak huni. Pada proses yang berlangsung, menjalankan program secara prosedural sangat memerlukan kerja keras dari penjajakan di lapangan, pendekatan ke masyarakat, memotivasi proses pembangunan dan sebagainya sehingga hasil dapat dicapai sesuai dengan harapan. Namun proses ini dihadapkan pada beberapa kendala yang krusial dan mungkin memerlukan langkah tindak lanjut untuk proses pada program berikutnya, agar berbagai hal terkait menjadi lebih tertata pada semua lapisan proses dan pihakpihak terkait.

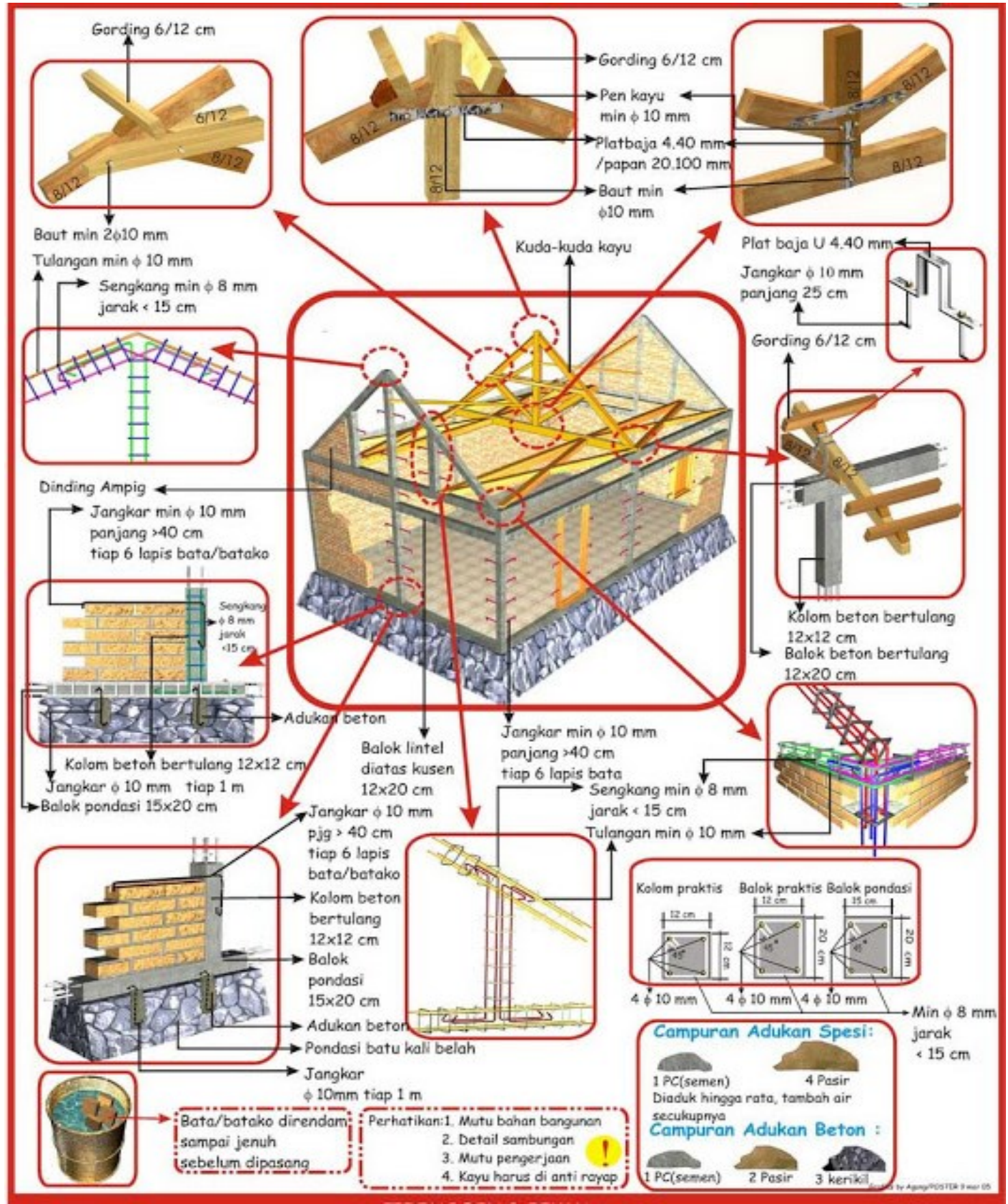

Gambar 2: Syarat minimum tembokan bata/batako tahan gempa dengan perkuatan beton bertulang. 


\section{KAJIAN SUMBER}

Rumah merupakan salah satu kebutuhan dalam kehidupan yang mencakup pada kebutuhan tersier. Sebagaimana fungsi sebagai tempat bernaung, rumah seharusnya memiliki elemen kelayakan yang sepatutnya menjadi bahan pertimbangan untuk kenyamanan penghuninya. Hal ini telah tersirat dalam Undang Undang Republik Indonesia Nomor 1 Tahun 2011 yang mengatakan rumah adalah bangunan gedung yang berfungsi sebagai tempat tinggal yang layak huni, sarana pembinaan keluarga, cerminan harkat dan martabat penghuninya, serta aset bagi pemiliknya (UU RI No. 1, 2011). Sedangkan pendapat yang sama oleh World Health Organization mengatakan rumah adalah struktur fisik atau bangunan untuk tempat berlindung, dimana lingkungan berguna untuk jasmani dan rohani serta keadaan sosialnya baik demi kesehatan keluarga dan individu (WHO, 2001). Wacana tersebut cukup jelas mengasumsikan bahwa rumah atau tempat tinggal memiliki peranan penting bagi manusia, tidak hanya pada kebutuhan bernaung saja namun secara fisik juga perlu perhatian khusus sebagai unsur keamaannya.

Sebagaimana penjelasan paragraf sebelumnya, rumah merupakan tempat berlindung dari beragam hal kejadian alam. Sejalan dengan hal tersebut, menurut Suharmadi (1985) rumah adalah tempat hunian atau berlindung dari pengaruh keadaan alam sekitarnya (hujan dan panas) serta merupakan tempat untuk beristirahat setelah melakukan aktifitas untuk memenuhi kebutuhan sehari-hari. Benang merah dari beragam sumber tersebut menjadi, pertimbangan hunian layak perlu memikirkan juga proses pembangunannya beserta ketahanan rumah tersebut dalam menghadapi cuaca dan keadaan fenomena alam lainnya. Kekokohan sebuah hunian mesti tetap memikirkan fungsi sebenarnya, karena rumah ataupun hunian ini sekaligus menjadi salah satu tempat beraktifitas sehari-hari. Pendapat tersebut sejalan dengan pendapat bahwa Rumah harus dapat mewadahi kegiatan penghuninya dan cukup luas bagi seluruh pemakainya, sehingga kebutuhan ruang dan aktifitas setiap penghuninya dapat berjalan dengan baik. Lingkungan rumah juga sebaiknya terhindar dari faktorfaktor yang dapat merugikan kesehatan (Hindarto, 2007). Dalam Undang - undang Nomor 4 Tahun 1992 tentang Perumahan dan permukiman, perumahan adalah kelompok rumah yang berfungsi sebagai lingkungan tempat tinggal atau lingkungan hunian yang dilengkapi dengan prasarana dan sarana lingkungan.

Rumah swadaya adalah rumah yang dibangun atas prakarsa dan upaya masyarakat (UU Nomor 01 Tahun 2011 Tentang Perumahan dan Kawasan Permukiman ) Perumahan Swadaya adalah kumpulan rumah swadaya sebagai bagian dari permukiman baik perkotaan maupun pedesaan yang dilengkapi dengan PSU (pemen PUPR 7/PRT/M/2018 tentang BSPS). BSPS adalah Bantuan Stimulan Perumahan Swadaya yang merupakan salah satu program pemerintah yang dilaksanakan secara berkala setiap tahun yang bertujuan untuk mendorong dan meningkatkan keswadayaan dalam peningkatan kualitas rumah dan pembangunan rumah baru serta PSU.

Tujuan dari penulisan ini adalah; 1) agar masyarakat umum mengetahui bahwa program pemerintah terutama dalam bidang perumahan bukan hanya berupa bedah rumah namun terdapat program yang dikerjakan secara swadaya yaitu BSPS, bahwa program BSPS ini dilaksanakan secara transparan dan menyasar Rumah Tangga yang 
benar-benar memiliki rumah yang tidak layak huni namun sanggup berswadaya; 2) Ketertarikan akan rumah tidak layak huni yang terdapat di desa Tusan disebabkan karena rumah tersebut dibangun rata-rata 30 tahun yang lalu, dan walaupun termasuk dalam kategori tidak layak huni bukan disebabkan karena kriteria pada umumnya tapi lebih diakibatkan karena usia tua dan cara pengerjaan bangunan tersebut yang belum mengenal sloof, kolom maupun ring sesuai dengan standar yang berlaku.

\section{METODE}

Pada penelitian ini, pengumpulan data berdasarkan data dari segenap lapisan yang berkolaborasi dalam proses serta data yang tedapat dilapangan sebagai perbandingan. Setelah data terkumpul maka segenap komponen yang ada pada data tersebut dianalisis dengan melakukan pemilahan kriteria yang muncul, misal analisis pada kendala lapangan dan solusi kendala-kendala tersebut. Pada akhirnya, beragam kendala dapat diselesaikan dengan baik dan sesuai dengan prosedur yang telah ditetapkan.

Metode penentuan informan, dengan menggunakan metode purposive sampling yaitu menentukan informannya dengan pertimbangan atau kriteria tertentu (Sugiono, 2011 :85). Dalam hal ini kriteria yang ada ditentukan berdasarkan asumsi yaitu warga yang menetap dan berdomisili di Desa Tusan, belum memiliki rumah atau memiliki dan menempati satu-satunya Rumah dengan kondisi yang tidak layak huni, berpenghasilan kurang dari Upah Minimum Daerah yaitu Rp. 2.338.840,00 di Tahun 2019 (https://upahminimum.info/umr-bali-terbaru.html), belum pernah mendapatkan bantuan berupa BSPS atau bantuan pemerintah untuk Program Perumahan, dan sanggup berswadaya serta membentuk Kelompok Penerima Bantuan (KPB) dengan pernyataan tanggung renteng/bergotong royong.

Pengumpulan data berdasarkan proses/ mekanisme BSPS dan penyalurannya akan dijelaskan pada gambar 3 berdasarkan infografis mekanisme dari PUPR. Datadata tersebut terfokus berdasarkan data yang dikumpulkan secara kolektif di Desa Tusan Kecamatan Banjarangkan, Kabupaten Klungkung dan dijabarkan sebagai berikut.

1. Calon Penerima Bantuan (CPB) ditentukan atas usulan dari Bupati atau walikota setempat. Data-data tersebut didapatkan melalui rekomendasi dari Desa Tusan berdasarkan atas usulan dari masyarakat yang dikumpulkan secara kolektif pada pemerintahan di tingkat desa Tusan.

2. Proses dilanjutkan melalui rapat koordinasi (rakor) atau musyawarah perencanaan pembangunan (musrembang).

3. Penetapan Lokasi oleh Direktorat Jenderal (Dirjen) Perumahan Swadaya.

4. Dirjen menunjuk satuan kerja (Satker) dan Satuan Kerja Perangkat Daerah (SKPD) yang bertugas untuk sosialisasi dan rekrutment serta pembekalan fasilitator.Salah satu tugas fasilitator melakukan sosialisasi, penyuluhan dan pembekalan masyarakat

5. Sebelum menentukan CPB, pemerintah kabupaten/kota wajib melakukan penyuluhan dan verifikasi yang merupakan salah satu tugas TFL, dan setelah proses verifikasi makan akan dibentuk Kelompok Penerima Bantuan (KPB) dan penetapan KPB 
6. Pemerintah Kabupaten / kota Klungkung akan melakukan penyusunan proposal yang terdiri dari survey toko penyedia bahan bangunan, dan kesepakatan pemilihan toko.

7. Membuat kontrak dengan toko penyusunan rencana penggunaan dana (RPD) dan penyusunan daftar rencana pembelian bahan bangunan (DRPB).

8. Tim Teknis Kabupaten/kota Klungkung mulai melakukan verifikasi, pengesahan dan pengusulan proposal untuk mendapatkan penetapan surat keputusan penerima bantuan oleh Pejabat Pembuat Komitmen (PPK).

9. Penyaluran dana BSPS oleh bank atau pos penyalur kepada MBR selaku pemesan bahan bangunan ke toko.

10. Pihak toko akan diperiksa sebelum menyerahkan bahan bangunan ke MBR yang dilanjutkan dengan pembayaran via trasnfer ke rekening bank yang sudah ditentukan.

11. Proses pembangunan atau perbaikan rumah swadaya mulai dilaksanakan.

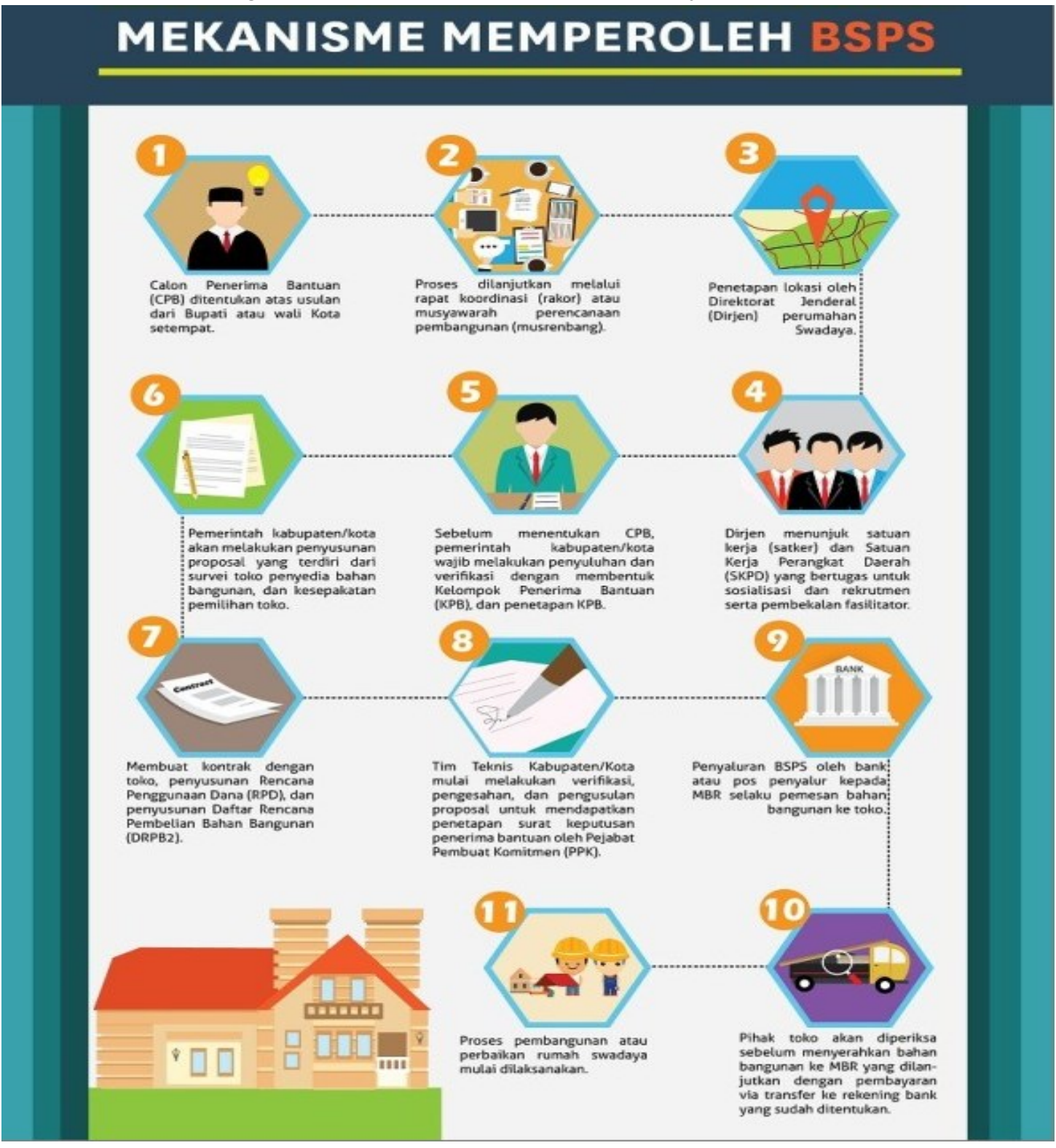

Gambar 3: Infografis mekanisme memperoleh BSPS. 


\section{PEMBAHASAN}

Program BSPS di Kabupaten Klungkung yang terfokus di desa Tusan kecamatan Banjarangkan, mengacu pada Permen PUPR No 07/PRT/M/2018 tentang BSPS, proses yang harus dilaksanakan mengacu pada struktur Gambar 4.

\section{TAHAPAN PENYELENGGARAAN BSPS}

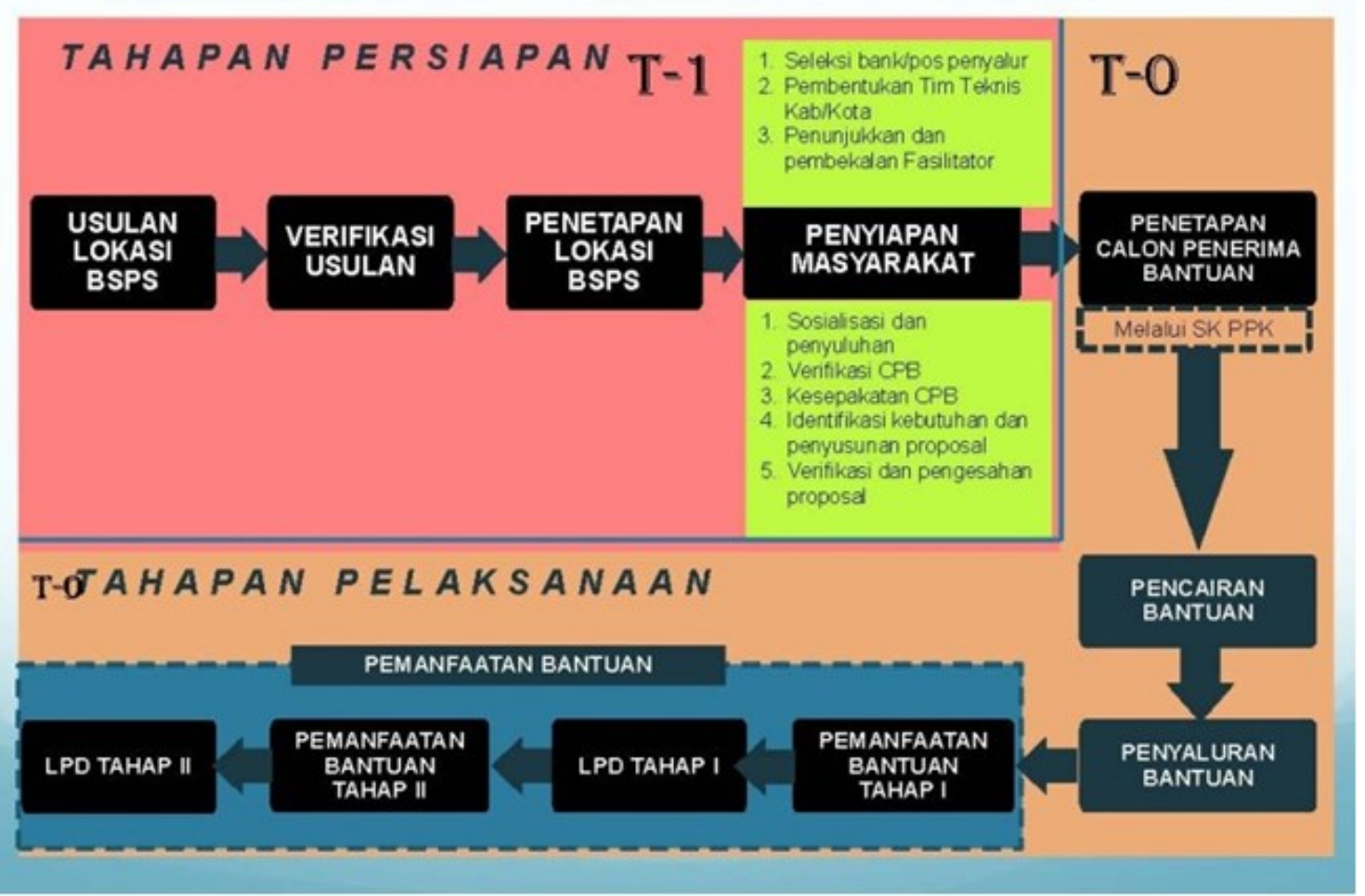

Gambar 4: Diagram Alir Tahapan Penyenggaraan BSPS . Sumber: Kementerian BSPS.

Penjabaran Gambar 4 dimulai setelah perekrutan Tenaga Fasilitator Lapangan (TFL) berdasarkan data usulan lokasi dan nama-nama calon penerima manfaat BSPS. Nama-nama tersebut merupakan data yang dikumpulkan secara kolektif oleh Tim Teknis berdasarkan usulan dari warga Desa Tusan. TFL kemudian mengadakan sosialisasi bersama Tim Teknis Desa yaitu Perbekel dan perangkat desa terkait beserta Calon Penerima Bantuan (CPB). Proses sosialisasi, TFL memberikan penyuluhan dan pengenalan tentang program BSPS dilanjutkan dengan melakukan verifikasi berdasarkan data BNBA (By Name By Address) yang sudah diberikan. Terdapat beberapa persyaratan yang harus dipenuhi CPB yaitu Warga negara Indonesia yang dibuktikan dengan adanya KTP dan KK, sudah menikah, memiliki surat keterangan hak atas tanah berupa sertifikat atau surat keterangan dari desa Tusan, memiliki penghasilan di bawah UMK Klungkung, belum pernah menerima bantuan BSPS atau sejenis BSPS, belum memiliki rumah atau memiliki dan menempati satusatunya rumah dengan kondisi tidak layak huni, bersedia berswadaya dan membentuk Kelompok Penerima Bantuan (KPB) dengan pernyataan tanggung renteng.

Dipenuhinya persyaratan oleh CPB, maka pelaksanaan kesepakatan dengan membentuk KPB, dimana KPB dipilih berdasarkan kedekatan lokasi antara masingmasing CPB sehingga memudahkan komunikasi dari tahap awal pada saat pembuatan 
proposal dan RAB maupun di tahapan konstruksi. TFL bertugas mendampingi CPB dalam pengajuan dan penyusunan proposal, melaksanakan identifikasi kebutuhan, melaksanakan survey toko yang dilaksanakan oleh KPB dan mendampingi CPB dalam penyusunan RAB berdasarkan harga toko yang telah terpilih sebagai suplier bahan bangunan yang akan mensuplai semua kebutuhan pada saat proses konstruksi.

Penetapan Calon Penerima Bantuan (CPB) menjadi Penerima Bantuan (PB) ditetapkan berdasarkan SK yang diterbitkan oleh Pejabat Pembuat Komitmen (PPK) Rumah Swadaya Satuan Kerja Non Vertikal Tertentu (SNVT) Penyediaan Perumahan Kementerian PUPR. Pencairan Dana BSPS melalui bank yang telah ditunjuk oleh SNVT. Penerima Bantuan melaksanakan penandatangangan buku tabungan sebelum rehab rumah dilaksanakan. Pembayaran tahap 1 diterima oleh toko bangunan ketika Penerima Bantuan (PB) telah menerima bahan bantuan secara lengkap sesuai dengan DRPB 1 (Daftar Rencana Pemanfaatan Bantuan). Selanjutnya toko akan mendapatkan pembayaran Tahap 2 setelah Progress Rehab rumah minimal $30 \%$ dari RAB.

\section{Analisis Permasalahan}

Pada pelaksaan BSPS di lapangan terdapat beberapa kendala yang krusial. Permasalahan tersebut diketegorikan yaitu kendala sosial, kendala edukasi, dan kendala situasi. Kendala-kendala tersebut dapat dijabarkan yaitu:

- Kendala sosial yang dimaksud adalah hubungan antar individu pada lingkungan Desa tusan yakni PB enggan melakukan kolaborasi dengan individu di luar dari lingkungan Desa Tusan, walau terjadi kekurangan tenaga kerja lokal yang menguasai secara teknis proses yang akan dilaksanakan.

- Kendala edukasi yang dimaksud adalah latar pengetahuan PB yang terbatas dan terbentuk secara alamiah dalam artian pelaksanaan proses pembangunan atas dasar pengalaman serta tidak melalui pendidikan format yang berkaitan. Kendala tersebut yakni penyusunan proposal yang relatif dianggap sulit dan memakan waktu, disebabkan pemahaman bahasa dan maksud yang tertera dalam format formalitas proposal beserta manfaatnya. Munculnya anggapan PB tentang penggunaan material yang tidak sesuai dengan pengalaman mereka. Kendala lain, egoisme PB yang menganggap dirinya sangat berpengalaman dalam hal bangunan walau kenyataannya sangat tidak memenuhi standar.

- Kendala situasi yang dimaksud adalah kendala yang muncul dikarenakan kondisional secara umum di Desa Tusan. Terkait hal tersebut yaitu adanya keterlambatan penjadwalan pembangunan, dikarenakan adanya kegiatan adat dan keagamaan di desa setempat. Kegiatan tersebut memakan waktu yang relatif panjang sehingga berdampak pada kesesuaian jadwal yang telah direncanakan sejak awal.

\section{Solusi Kendala Lapangan}

Adapun solusi untuk menjawab analisis kendala pada sub sebelumnya yaitu:

- Kendala sosial: TFL mengadakan pendampingan, memotivasi PB agar berswadaya tenaga kerja sesuai dengan keahlian dan berkolaborasi dengan PB lain sesuai dengan fungsi dibentuknya KPB.

- Kendala edukasi: mendampingi Penerima bantuan secara terus menerus dan berkesimbangungan agar PB dapat menyelesaikan penyusunan proposal dan rab 
sesuai dengan persyaratan formal. Memberikan pemahaman kepada PB tentang kostruksi yang aman dan sesuai dengan standarisasi rumah layak huni.Menegaskan kepada penerima bantuan dan tenaga kerja, program BSPS bertujuan untuk meningkatkan kualitas rumah agar memenuhi kriteria rumah layak huni dan PB beserta tenaga kerja harus mematuhi segala ketentuan yang berlaku.

- Kendala situasi: keterlambatan akibat kegiatan keagamaan dan adat yang tidak dapat dipisahkan dari kehidupan masyarakat desa Tusan dapat diantisipasi dengan memanfaatkan waktu luang semaksimal mungkin. Tanggung renteng merupakan salah satu hal yang mutlak dilaksanakan PB untuk menyikapi keterlambatan progress pembangunan agar dapat selesai tepat waktu.Prinsip tanggung renteng ini berhubungan pula dengan solusi untuk mengatasi kendala sosial.



Gambar 5: Kondisi Awal Rumah Ni Nyoman Darsi (PB)

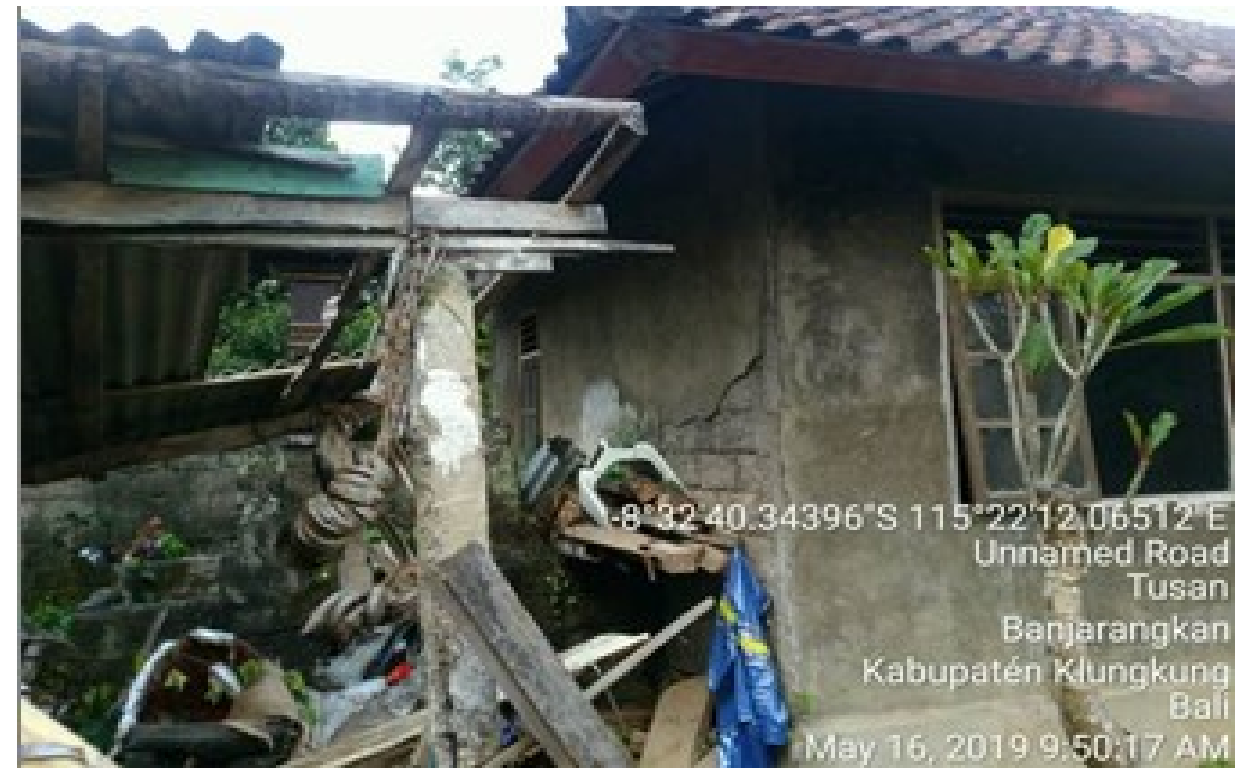

Gambar 6: Persentase Kerusakan tanpa sloof, kolom dan ring, kerusakan pintu dan jendela. 


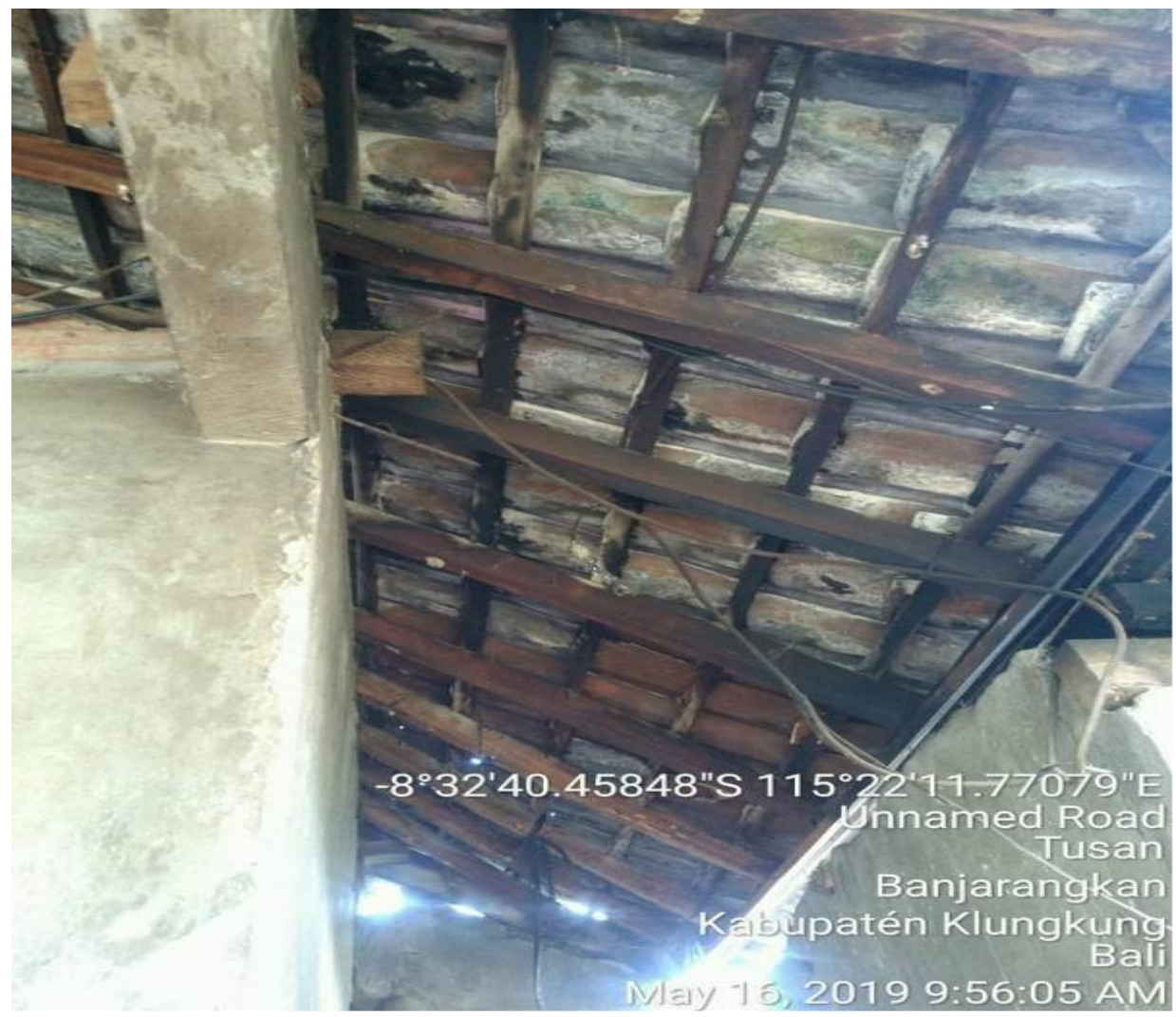

Gambar 7: Persentase Kerusakan struktur atap dan kerusakan penutup atap.

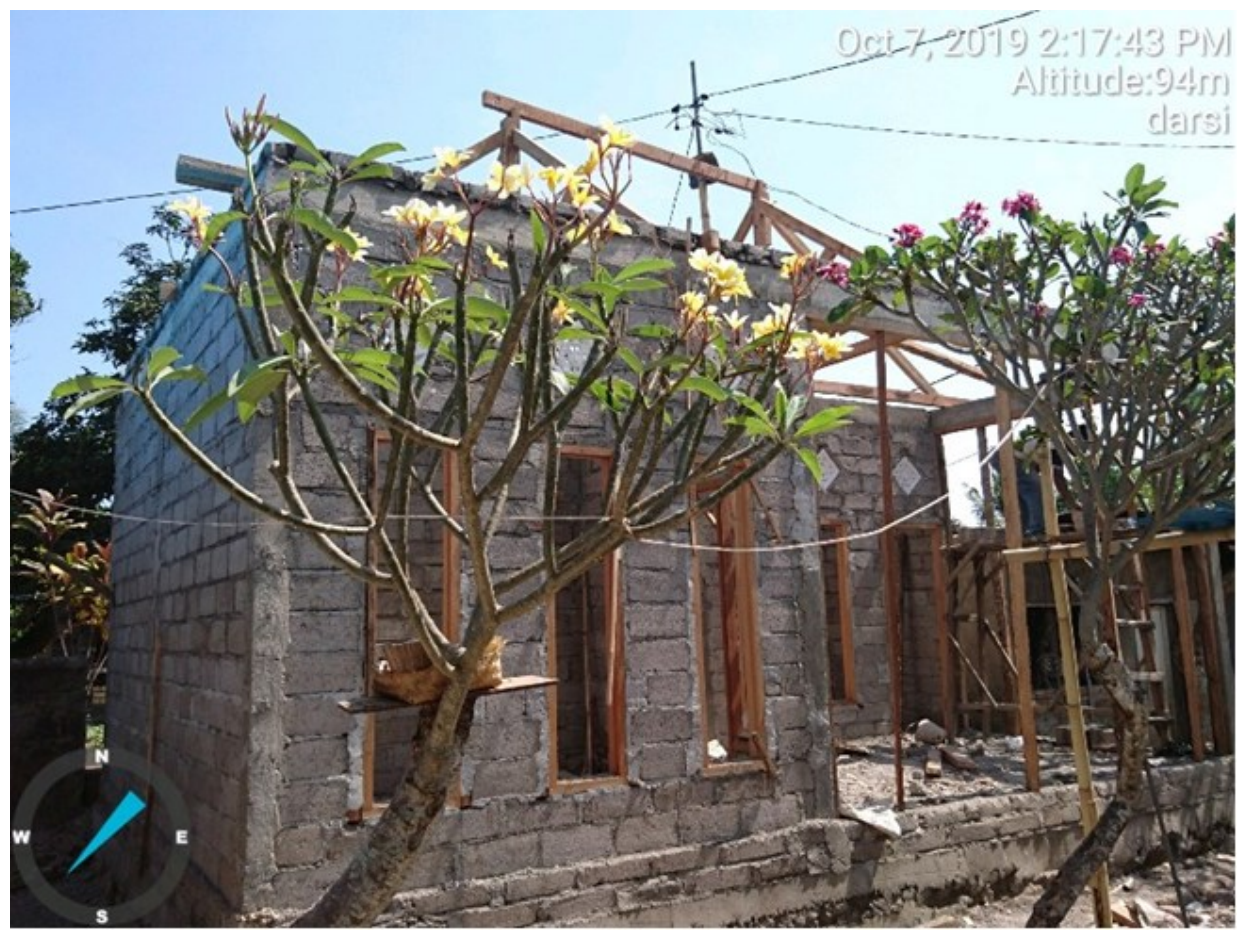

Gambar 8: Persentase Proses Konstruksi. 


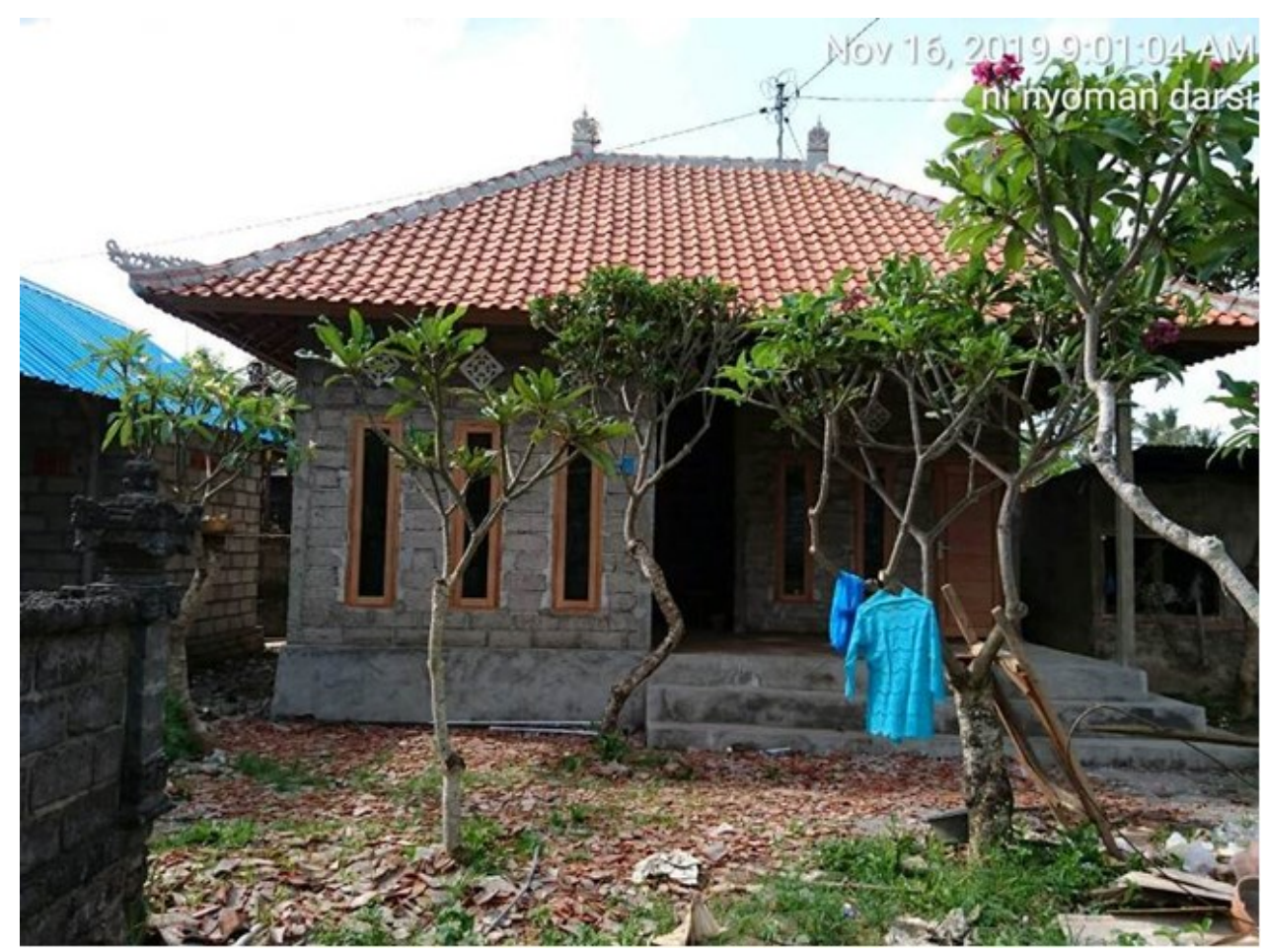

Gambar 9: Kondisi 100\% setelah mendapat bantuan BSPS.

SIMPULAN

Pelaksanaan program BSPS yang dilaksanakan di Desa Tusan mengacu pada pembahasan analisis kendala dan solusi, dapat dijabarkan sebagai berikut. Secara garis besar, kendala yang muncul dan krusial terdiri dari 3 hal yaitu kendala sosial, kendala edukasi dan kendala situasi. Hal ini perlu disikapi dengan intensitas pendampingan yang kontinyu dan berkesinambungan.

Pendampingan dapat merubah sudut pandang masyarakat secara luas tentang standarisasi rumah layak huni agar sesuai dengan kriteria yang ada. Sinergi antara masyarakat, aparat desa dan pemerintahan secara regional harus terus ditingkatkan, dan perlu dilakukan kajian secara konprehensif yang berhubungan dengan kendala di lapangan.

Pelaksanaan BSPS di desa Tusan sudah memenuhi prosedur sesuai dengan yang diamanatkan oleh Permen PUPR No 7 Tahun 2018. Salah satu tolak ukur keberhasilan program BSPS di desa Tusan adalah alokasi bantuan yang tepat sasaran tanpa adanya intervensi dari pihak tertentu.

\section{REFERENSI}

Badan Standar Nasional Indonesia. 1990. SNI 03-1979-1990 tentang Matra Ruang. Badan Standardisasi Nasional: Jakarta.

Dipohusodo, Istimawan.1996. "Manajemen Proyek \& Konstruksi”. Kanisius: Jogjakarta. Hindarto, P. 2007. "Inspirasi Rumah Sehat di Perkotaan”. Andi: Yogyakarta.

Kabupaten Klungkung. Kondisi Geografis, diakses 12 Juni 2019 pada http://klungkungkab.go.id/page/kondisi-geografis.html.

Komisi WHO Mengenai Kesehatan dan Lingkungan . 2001. Planet Kita Kesehatan Kita. Kusnanto H (Editor). Yogyakarta : Gajah Mada University Press, p. 279. 
Peraturan Menteri Pekerjaan Umum Dan Perumahan Rakyat Republik Indonesia Nomor 07/PRT/M/2018 tentang Bantuan Stimulan Perumahan Swadaya.

Suharmadi. 1985. Perumahan Sehat, Proyek Pengembangan pendidikan tenaga Kesehatan Departemen Kesehatan RI. Jakarta.

Sugiyono. 2011. "Metode Penelitian Kuantitatif Kualitatif dan R\&B", Alfabeta, Bandung.Undang-undang Republik Indonesia Nomor 4 Tahun 1992 Tentang Perumahan Dan Permukiman.

Sutaryo ; Kusdjono. 1984. "Kamus Istilah Teknik Sipil". Depdikbud: Jakarta.

UMP Bali. Daftar UMR Bali 2019 Terbaru, Tahun 2019 Naik Lagi 8,03\%, diakses 11 Juni 2019 pada https://upahminimum.info/umr-bali-terbaru.html.

Undang-undang Republik Indonesia Nomor 1 Tahun 2011 Tentang Perumahan Dan Kawasan Permukiman. 